\title{
Undervisningens gavegivning
}

\author{
Thomas Aastrup Rømer, lektor, ph.d., \\ Aarhus Universitet, thomas-r@edu.au.dk
}

\begin{abstract}
Resumé
I denne artikel undersøges undervisningsbegrebets aktuelle tilstand og dets filosofiske indhold og muligheder. Først argumenteres for, at undervisningsbegrebet i dets nuværende brug reduceres til at være en metode, der skal optimere konstruktivistisk læring, som har det store problem, at det bygger på en afvisning af undervisning selv. Dernæst undersøges fire forskellige nyere bidrag til et undervisningsbegreb, som kan forstås helt uafhængigt af konstruktivistisk læring. Via analyser af Daniel Breslauers, Gert Biestas, Chris Higgins og Jan Masscheleins pædagogiske filosofi argumenteres for, at undervisning består af en dobbelt gavegivningsproces, som sætter læreren og eleven i et langt mere tæt, kulturelt og vekselvirkende samspil end hidtil.
\end{abstract}

\section{Nøgleord}

Undervisning, læring, kausalitet, gave, filosofi.

Vi har i mange år fokuseret på læringsbegrebet. I politiske og administrative kredse tales ligefrem om en læringsrevolution, og ofte ledsages revolutionen af slogans som "fra undervisning til læring". Også i forskerkredse har tendensen bredt sig i et omfang, så Gert Biesta i en kritisk diskussion af netop dette læringsfokus siger, at vi er nået til "the end or even the death of the teacher" (Biesta, 2013, s. 46).

I denne artikel vil jeg kort give min egen version af denne kritik. Først vil jeg pege på, at den eksisterende forståelse af forholdet mellem undervisning og læring bygger på en forveksling af kausalitetsforholdet, altså det som metodelæren kalder for den uafhængige og den afhængige variabel. Jeg vil argumentere for, at den uafhængige variabel, altså undervisning, i aktuel forskning defineres ved den afhængige variabel, altså læring. Det betyder, at vi ikke kan fastlægge nogen pædagogisk kausalitet og i stedet ender med at konstruere en teknisk forbindelse.

Den betragtning er afsæt for en nærmere undersøgelse af, hvad den uafhængige variabel er i sin fulde uafhængighed, dvs., hvad undervisning er 
uden læringsbegrebets determinerende tilstedeværelse. Til det formål har jeg fundet en række tilgange, der diskuterer undervisning i egen ret, og som har forskellige former for betydning for vores aktuelle diskussioner om emnet. Det drejer sig om dels om en helt ny artikel af Daniel Breslauer, hvor Israels pædagogiske filosofi diskuteres, dels en bog af amerikaneren Chris Higgins, der sætter undervisning i forbindelse med det gode liv, dels et kapitel hos netop Gert Biesta, hvor undervisning tematiseres via en refleksion over Søren Kierkegaards filosofi, og endelig en kort omtale af belgieren Jan Masscheleins opfattelse af skolen som "suspension" samt hans ledsagende idé om, at det pædagogiske liv handler om at bringe tingslighed og subjektivitet tæt på hinanden. Selvom disse tilgange er forskellige på mange måder, så deler de idéen om, at undervisning kan opfattes som en gave, og det er den fælleshed, jeg gerne vil fremskrive i det følgende.

\section{Kritikken: Den omvendte kausalitet}

Hvis man ønsker at finde en egentlig pædagogisk kausalitet, altså at stille spørgsmålet op som at undervisning skal føre til læring, så kræver det en undersøgelse af de begreber, som man anvender, samt en undersøgelse af, hvordan de påvirker hinanden i den parallelle pædagogiske realitet. Man skelner derfor i metodelæren mellem den uafhængige og den afhængige variabel. Den uafhængige variabel er knyttet til det objekt, der antages at være "årsagen", altså i dette tilfælde "undervisning". Den afhængige variabel er derimod effektvariablen, altså læring. Min korte pointe her er, at meget aktuel pædagogisk forskning forveksler denne sammenhæng. Dvs., at den bestemmer den uafhængige variabel ved den afhængige i det, som er blevet kaldt for "omvendt kausalitet" (Hariri, 2012). Derved bures forskningen inde i en konstruktion. Lad mig forklare det:

a. Den afhængige variabel, altså læringsbegrebet, er defineret som anti-undervisning Det læringsbegreb, der er i vælten for tiden, er den såkaldte radikale konstruktivismes læringsbegreb (Glasersfeld, 1995). Her defineres læring som subjektive konstruktionsprocesser. Der er stort set ingen tematisering af omverden, kultur, dannelse og politik. Det er klart, at undervisning under dette begrebsmæssige vilkår kommer under pres, og den reduceres da også ofte til "instruction" eller til "designing", hvis den da ikke helt falder ud og overgår til "the death of the teacher". Læreren ender som en form for tekniker, der transmitterer atomiserede videnselementer, eller som en person, 
der som en neutral tekniker tilrettelægger og designer læreprocesser. Nogle gange reduceres læreren endda til at være "privatpraktiserende" eller "enevældig", dvs. knyttet til et normativt opgør med noget, man kalder for "den sorte skole". Dette læringsbegreb overtages på forskellige måder både af f.eks. systemteorien og af John Hattie med den effekt, at subjektive konstruktioner tematiseres som et såkaldt "læringsudbytte", dvs. som målelige og synlige elementer, der kan omsættes til rådatalandskaber, som efterfølgende kan styres og evalueres efter nærmere bestemte organiseringer og systemer (Qvortrup, 2015). Overordnet set hænger dette opgør med undervisning sammen med et opgør med almendannelse og pædagogiske formål som sådan, men det lader jeg ligge her.

Endelig vil jeg kort sige, at Glasersfelds arbejde har præget både Niklas Luhmann, John Hattie, John Biggs og vores hjemlige Jens Rasmussen dybt, hvilket jeg har redegjort for i andre sammenhænge (Rømer, 2015; 2017a; 2017b). Det er via disse forbindelser, at den radikale konstruktivisme har sat sig så kraftfuldt igennem i centrale dele af pædagogisk teori og den tilhørende uddannelsespolitik.

Med denne bestemmelse får vi en afhængig variabel, nemlig læring, hvis begreb er bestemt i modsætning til og ligefrem i et opgør med både mere socialt tematiserede læringsforståelser og med undervisningsbegrebet som sådan. Den afhængige variabel er altså defineret ved et opgør med den uafhængige. Allerede her lyder det problematisk, men det bliver værre.

b. Undervisning som metode for opgør med undervisning Spørgsmålet er nu: Hvad sker der, når undervisningsbegrebet, som jo er udelukket, vender tilbage igen, på udelukkelsens præmisser vel at mærke? Jo, først og fremmest må undervisningsbegrebet tilpasse sig den specifikt konstruktivistiske version af læringsbegrebet, som jeg netop har omtalt. Dvs., at 'undervisning' må smide sine filosofiske, normative og sociale aspekter bort. Undervisning mister sin omverden, fordi den må tage farve af den afhængige variabels solipsisme.

Desuden sker der det, at undervisning bliver til et middel for den undervisningsafvisende læring, dvs. for sin egen nu etablerede antagonisme. Undervisning, som jo er defineret ved det begreb, som vil af med undervisningen selv, vender nu tilbage som læringens tjener. Undervisning reduceres dermed til én blandt andre læringsmetoder. Undervisning bidrager sammen med alt muligt andet til 'læringsoptimering'. Denne proces er også blevet kaldt "klasseledelse all inclusive" (Staunæs \& Juelskjær, 2014). 
Men dermed sker der en tankevækkende forskydning. For når man definerer en uafhængig variabel ved den afhængige, hvis altså undervisning er helt underlagt en læring, der er defineret ved en afvisning af undervisningen selv, ja så har man jo slet ikke en uafhængig variabel mere. Det, man altså får etableret via sine empiriske undersøgelser, er derfor en form for lukket bur med kvantificeret læring og tekniske metoder. Den virkelige undervisning og den virkelige læring får man ikke øje på. Sådan er det, fordi begreberne arbejder, som de gør. Begreberne binder sig til hinanden i en uheldig symbiose.

Men det går jo ikke. Det ødelægger både pædagogikken og den pædagogiske forskning. Vi vil have virkelig kausalitet med adækvate begreber og fuld empiri. Derfor må vi undersøge både læringsbegrebet og undervisningsbegrebet i deres egen ret, og i nærværende sammenhæng er det så undervisningsbegrebet, der er i fokus. Så spørgsmålet er: Hvad er det for en uafhængig variabel, vi taler om, når den anskues i fuld, nå ja... i fuld uafhængighed? Ja, faktisk før den overhovedet kommer til syne som "en variabel".

Vi må derfor undersøge den uafhængige variabels nærmere karakter, når den anskues i sig selv, for at se, om pædagogikken og den pædagogiske forskning kan komme tættere på begrebernes realitet. Her kommer fire bud, som nok er forskellige, men som også har mange ting tilfælles.

\section{Undervisning som national essens}

I et aktuelt nummer af tidsskriftet Studies in Philosophy and Education er der en interessant artikel af amerikaneren Daniel Breslauer (Breslauer, 2016). Breslauer forsker i forholdet mellem pædagogik og teologi, hvilket vi jo selv har en rig tradition for her i landet. Artiklen handler om karakteren af den nationale pædagogik i Israel, og min pointe skal være, at vi kan lære noget af denne diskussion, noget om betydningen af national essens, et udtryk som herhjemme nærmest er et bandeord. Artiklen hedder "Martin Buber's Myth of Zion: National Education or Counter-Education".

Spørgsmålet, der behandles, er som sagt, hvilken pædagogisk filosofi, der bør præge Israel som nation. Forfatteren gør op med to eksisterende positioner og forsøger sig med en drøftelse af Martin Bubers ideer i stedet. Den ene position, som kritiseres, er den uddannelsestænkning, der kommer til udtryk i traditionel nationalistisk policy. Her handler det om at uddanne til jødisk patriotisme i en form for identitetspolitisk prægning. Det omtales 
som en "degenereret nationalisme", hvor borgerne er reduceret til "symbols of a national ideology".

Den anden position drøftes mere indgående, fordi den har haft en ret fremtrædende plads inden for den pædagogiske filosofi, også i europæiske og amerikanske kredse. Det er den særlige form for kritisk pædagogik, som er udviklet af den pædagogiske filosof Ilan Gur-Ze'ev, som selv er jødisk. Ze'ev afviser "all national education". I stedet idealiserer han den jødiske diaspora, dvs. landflygtigheden. Denne idé om diasporaen, som Gur-Ze'ev generaliserer til en almen uddannelsesfilosofisk markør, lægger vægt på fremmedheden, forladtheden, udelukkelsen og det nomadiske, og på en måde er det lidt pudsigt, at Gur-Ze'ev trækker på et jødisk grundbegreb i et opgør med en national pædagogik. Faktisk kan man se figuren dukke op flere steder i de mest avancerede poststrukturalistiske kredse. Alphonso Lingis, der ligesom Gur-Ze'ev har rødder i Levinas' filosofi, har samme idé i sin bogtitel: "The community of those who have nothing in common". Og hos Foucault, som både Lingis og Gur-Ze'ev er inspireret af, finder vi også idéen om pædagogik som noget, der opererer på samfundets diskursive grænseflader. Idéen findes også hos Rousseau, hvor Émile også tages ud af samfundet, for kun derude kan han få en god opdragelse. På en måde er det en almen kritisk figur, som her får en jødisk prægning i en særegen form for opgør med israelsk identitetspolitik. Gur-Ze'ev mener ligefrem, at Israels fokus på Holocaust har mindsket landets sensitivitet for andre undertrykkelseshandlinger. Han kan derfor direkte sige: "Israel has become the ultimate Diaspora of the Jewish spirit" (Breslauer, 2016, s.505).

Men Breslauer vil gerne finde en mellemvej, dvs. en national opdragelse, som både er knyttet til sted, dvs. som ikke radikaliserer diasporaen i dens egen opløsning, men som også undgår den identitetspolitiske lukkethed, som præger den politiske nationalisme. Til det formål trækkes på Martin Buber, der er bredt kendt i uddannelsesfilosofien - også i visse skandinaviske sammenhænge - for sit fokus på dialog, dvs. på vekselvirkningen mellem jeg'et og du'et og det'et og disses grundlæggende både konstitutive og åbne karakterer. Buber var også blandt ideologerne bag den alternative zion-bevægelse, som prægede de socialistisk og humanistisk indstillede kibbutzer - en form for Robert Owens-lignende socialt eksperiment, som mange danske unge i øvrigt frekventerede langt op i 1980'erne via foreningen Dakiv. Bubers pointe var altså ikke en form for anti-nationalisme, men derimod at give nationen Israel en mere åben, social og kulturel forankring. Det var en anden form for nationalisme. Ifølge Breslauer kritiserede Buber 
en "degenereret nationalisme", som reducerer individer til at være repræsentanter for "a specific type" (s. 494). I stedet bliver Bubers og Breslauers spørgsmål: "what type appears?" i en fælles dialogisk og kulturel grund.

Undervisningsbegrebet hvirvles nu ind i en række bredere kulturelle refleksioner, som en særlig essens, en kropslig og sproglig transmission og en søgen efter Zions uudgrundelighed frem for en regelret identitetspolitisk implementering af Zion, hvis man kan sige det på den måde. Det handler om at forstå undervisningens indlejrethed i en kulturel dialog og $\mathrm{i}$ en praksis, som både er forankret, men som også er åben og undersøgende, og Bubers pointe er, at disse elementer arbejder i udveksling og transaktion mellem Jeg, Du og Det. Vi får det, som Breslauer kalder for "education in the between", hvor åndeligheden bryder frem inde fra relationernes indre.

Bresluaer taler om, at Buber bringer sin jødiske pædagogik ind i en humanistisk og moderne tid, og at denne pædagogik endda henvender sig til en form for verdensborgerlig dialog, a "total human attitude", som det hedder. Buber ønsker altså en både kulturel forankring og åben humanitet. Han taler om en israelsk borger, der er "responsible to mankind as a whole while being embedded within a concrete community" (s. 496). Ifølge Breslauer mente Buber, at denne filosofi var en del af den jødiske mytologiske essens, og der lægges derfor stor vægt på de narrative og mytologiske sider af pædagogikken. Fokus på fortælling og på sammenhængen mellem sted og universalisme minder om f.eks. Peter Kemp, som funderer kristendommen narrativt, og som i et aktuelt arbejde taler om en "dansk verdensborger" (Kemp, 2015, s.106), samt om mange steder i den grundtvigske tradition, hvor vi finder lignende temaer (f.eks. Jonas 2003).

Målet er en "cultivation of Hebrew humanism" (Breslauer, 2016, s. 502), en besindelse på Zions både fulde tilstedeværelse og radikale ubegribelighed $\mathrm{i}$ den konkrete dialog. Ifølge Breslauer er både "erindringen" og ikke mindst relationen til erindringen centrale dele af en jødisk identitet. At det er særligt prægnant i en jødisk tradition, giver sig selv. Vi får dermed en række fortolkningstraditioner, som udspringer af en åben og undersøgende omgang med kulturel erindring, og det er myterne og kunsten, der hele tiden skal holde disse processer åbne, så de ikke stivner i simpel identitetspolitik eller stikker af i Gur-Ze'evs diaspora-afvisende diaspora.

Det betyder, at en lærer er forbundet med sin nationale og mytisk-poetiske oprindelse i en form for essentiel åbenhed, både i forhold det kulturelle og videnskabelige materiale og i forhold til eleverne. Her er et centralt citat 
Thomas Aastrup Rømer: Undervisningens gavegivning

om Buber, hvor denne praktiske, ontologiske og pædagogiske "essens" betones:

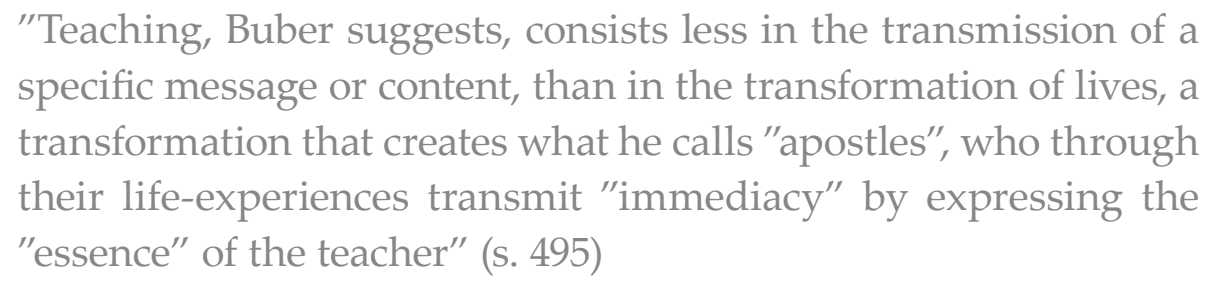

Undervisning er en "expression of essence". Den gode undervisning handler altså ikke om at leve op til angivne procedurer eller idealer. Den handler derimod om at blive væk i kundskabernes dybde sammen med den næste generation med de tekster og på de måder, som er knyttet til historisk undersøgende og levende processer. ${ }^{1}$ Undervisning er ved sin praksis en levendegørelse af en national og kulturel tradition. Hermed knyttes læreren til en national dialog, som konstant er til undersøgelse i fortællingernes skær. Læreren er en form for filter for national essens, der bringer dialog og åbenhed hen til samfundets og historiens materiale. Buber taler om en "ability to give to others and the ability to acknowledge what has been given". Undervisning er altså den særlige form for gave-givning og -modtagelse, som præger et givent lands tradition.

Bubers underviser har en lære snarere end et budskab. Pointen kommer bedre frem på engelsk: "The teacher has a teaching", som det hedder. Undervisning er altså en dialogisk og åben undersøgelse af fortællingers udvikling samt af lærerens og elevens egen eksistens heri. Undervisning er en udveksling af erindringsgaver. Ze'ev ville med sit kritisk-teoretiske udgangspunkt kalde det for 'opium for folket'. Buber vil kalde det for folket, slet og ret.

Nu kan man så spørge: Hvad har det med Danmark at gøre? Meget, efter min mening. Også i Danmark har vi en nationalistisk højrefløj, der arbejder identitetspolitisk. Men vi har også en venstrefløj, der minder om Gur-Ze'ev på forskellige måder. Lad mig først sige lidt om vores pædagogiske venstrefløj. Den refererer overhovedet ikke til Gur-Ze'ev, men den har samme fokus på "grænser". Det er især den Foucault-orienterede pædagogik, jeg her taler om. Traditionen nednormeres til strukturer, mens pædagogikken må arbejde på grænsefladerne mellem en konstrueret struktur og en anti-humanistisk subjektivitetsopløsning. I værste fald forsvinder mennesket helt. Det

Buber mente ligefrem, at hans filosofi ville kunne skabe varig fred med palæstinenserne. 
ser vi f.eks. i kredsene omkring konkurrencestatsteorien og i visse andre poststrukturalistiske miljøer. På en måde har vi en "radikaliseret" version af Gur-Ze'evs filosofi. Gur-Ze'ev refererede jo i det mindste til et kulturelt grundbegreb, nemlig disporaen. Det gør den danske venstrefløj ikke, fordi enhver form for national interesse med det samme fortolkes strukturelt eller identitetspolitisk. I den forbindelse kan man nævne centrum-venstres skolepolitiske initiativ "Ny Nordisk Skole", som var et ideologisk forsøg på at tale administrativt-affektivt til lærernes grundtvigske oprindelse. Netop $\mathrm{Ny}$ Nordisk Skole er dog omgivet af ca. samme centrum-venstre ideologi, som præger meget af den pædagogiske venstrefløj, nemlig dels accepten af konkurrencestatsteorien som et vilkår og dels accepten af det konstruktivistiske læringsbegreb, jeg omtalte i starten af kapitlet. Hermed ender Ny Nordisk Skole paradoksalt nok som et opgør med "det nordiske", og dermed fratages lærerne muligheden for at undervise i Bubers forstand.

Breslauers reference til Buber minder faktisk om vores egen grundtvigske tradition. Faktisk finder man sådan en reference i Breslauers tekst. Vi får at vide, at Buber var direkte influeret af tankerne bag den danske folkehøjskoletradition og dens "open and responsive atmosphere", som det hedder (s. 504).

I dag er grundtvigianismen i mange pædagogiske kredse placeret henne hos den identitetspolitiske nationalisme, men det er en historisk konkret fejl. Grundtvig har præget den danske venstrefløj dybt, langt op i 1980'erne, og spiller stadig en stor rolle for f.eks. Danmarks Lærerforenings professionsideal. I den forstand er han faktisk en endnu mere historisk samlende figur end Buber.

Grundtvigianismen har i øvrigt en række filosofiske momenter direkte tilfælles med Bubber, selvom der jo også er mange forskelle. En central lighed er idéen om dialog og vekselvirkning, som faktisk også findes i den desværre ret marginaliserede læringsteori, som har udviklet sig med udgangspunkt i russeren Bakhtins tanker, den såkaldte dialogisme (f.eks. Roth, 2009). En anden vigtig lighed er interessen for myter og fortællinger og for hele den teologiske og filosofiske grundstrukturering af pædagogikken. Det gælder om at holde en tradition levende både i dybden og i genskabelsen, på måder der helt undviger og endda undergraver forsøg på at reducere det nationale til strukturalisme eller "identitet".

$\mathrm{Nu}$ betyder denne refleksion ikke, at man så bare skal "anvende" idéer, som er 150 år gamle og delvist tidbundne. F.eks. var Grundtvig kritisk overfor moderne videnskab og dele af den tyske tradition, hvilket vi jo ikke bare 
sådan kan eller bør overtage. Det er ikke "meningerne", jeg taler om, men derimod undersøgelsen af hele denne nationale essens, som det også var Bubers opgave at finde, og som er dybt forbundet med både europæiske og universelle temaer. ${ }^{2}$

I den forstand er undervisningen i Danmark en del af en grundtvigsk tradition, der er blevet splittet i hhv. identitetspolitisk nationalisme og poststrukturalistisk anti-humanisme, og som nu arbejder i dybe forfaldsstrukturer. Spørgsmålet er så blot, hvad der kendetegner en dansk pædagogisk essens? Den særlige praksis, som en dansk skole ved dens egen praksis skal vise eleverne og indvie dem i. Den danske lærers lære. Dvs. den usynlige læring og kulturkredsens fortællingers betydning.

En revitaliseret fortolkning af den grundtvigske tradition, som har præget både højre og venstre dybt, ligger lige for. Jeg har selv påbegyndt et sådant arbejde via en analyse af teksten "Det danske firkløver". Her finder jeg et særligt begreb om autoritet og poesi, som også i dag går igen i mange pædagogiske diskussioner og sammenhænge (Rømer, 2015). Mere grundlæggende argumenterer jeg for, at Grundtvig opfatter en dansk essens som en passiv autoritet, der frigør folkelig tilsynekomst. Grundtvig fortæller også om en form for dobbelt gave-givning, hvor kongen får autoritet af folket som en gave, men hvor autoriteten derpå giver sin autoritet tilbage til folket, så vi får et "folkestyre", dvs. en passiv monark, som har givet al sin magt til undersåtter, som derved blev til et folk. Igen har vi "gave-begrebet", som noget måske meget grundlæggende, og i skolens formålsparagrafs allerførste sætning har vi også udtrykket at folkeskolen skal ...."give kundskaber". På den måde ender vi faktisk i nærheden af den oprindelige "nynordiske skole", som blev udviklet af grundtvigske kredse fra omkring 1930, men det lader jeg ligge her.

\section{Hen-given-hed: Undervisning som at modtage en gave}

Det andet nedslag er fra Gert Biestas nyeste bog The Beautiful Risk of Education (Biesta, 2013). Her forsøger Biesta med udgangspunkt i postmoderne teologi at argumentere for pædagogik som en "svag" aktivitet, dvs. at man ikke skaber ex nihilo, men formgiver allerede eksisterende materiale, som $i$ en vis forstand er uregerligt, deraf ordet "risk" i bogens titel. Læreren er

2 Interessen for fænomenologisk essens er stimuleret af den såkaldte "weird realism", som f.eks. Graham Harman og hans postmoderne Heidegger-læsninger spiller en central rolle i (Harman, 2005). 
altså ikke omnipotent, han "styrer" ikke. Men det betyder ikke, at læreren er en passiv læringsdesigner eller en sokratisk jordemoder, hvilket jo ofte markeres som alternativerne. Læringsdesigneren udelukkes via en gentagelse af Biestas legendariske læringskritik fra 2004, og det markeres også i et af afsnittenes overskrifter, som er: "Constructivism and the end of teaching" (Biesta, 2004 \& Biesta, 2014, s. 44). Og jordemodermetaforen og dermed vulgærplatonismen afvises allerede i kapitlets indledende Levinas-citat:

"Teaching is not reducible to maieutics; it comes from the exterior and brings me more than I contain".

Af citatet fremgår, at undervisning skal betragtes som en eksistentiel tilføjelse, et "mere" til mit indre, noget udefrakommende. Dette grundsyn udvides inde i teksten i et selvstændigt kapitel, som direkte hedder "teaching". Undervisningsbegrebet udarbejdes både med fortsat reference til Levinas og ikke mindst med solide tilknytninger til vores egen Søren Kierkegaard. Og sjovt nok er den lærer, Biesta finder der, meget langt fra at være "passiv" i den konstruktivistiske forstand. Men det er heller ikke skabelse ex nihilo og deraf afledt styring. Undervisning er muligheden for, at subjektivitet "can happen", som det hedder. Det handler om, at subjektifikation, eller med Hannah Arendts ord "natalitet", kan komme til syne, ja ligefrem bryde igennem. Biesta er altså i gang med at undersøge hvilken lærer, der passer til hans "dannelsesbegreb", dvs. subjektifikation, som jo er arendtsk defineret. Undervisningen er derfor en form for "event", noget der indtræffer, når en elev tager imod undervisning i en hen-given passivitet, der aktivt giver.

Biesta bestemmer læreren som en person, der "bringer noget nyt ind i den pædagogiske situation". Læreren må derfor komme udefra, fra et transcendent område. Undervisning er i den forstand "a gift" eller en "act of gift giving". Men dette kan ikke foruddiskonteres, det er en "svag" indgriben, for gaven skal også modtages. Derfor undersøger Biesta, hvad det vil sige, at gaven modtages, hvilket han understreger med en formulering, der giver bedst mening på engelsk: "being taught by" som modsætning til "to learn from" (som hører til læringsdiskursen, dvs. den omvendte kausalitet). Biesta taler om en "fundamental difference" mellem disse to tilgange (Biesta, 2013, s. 57). Med sin markering mener Biesta, at "undervisning" kan komme tilbage til pædagogikken, hvor den har været savnet siden læringsrevolutionens start. ${ }^{3} \mathrm{Vi}$ får altså et undervisningsbegreb, som både er transcendent

3 Det kapitel, jeg skriver om, blev oprindeligt udgivet som en artikel, hvis titel i højere grad udtrykker pointen: "Receiving the Gift of Teaching: From 'learning From' to 'being taught by' (Biesta, 2012). 
funderet, og som er betinget af undervisningens subjektive modtagelse. Det vil jeg uddybe lidt.

Den første pointe om det transcendente gennemløbes via en drøftelse af Platon-dialogen Menon, hvor Sokrates kobles til konstruktivismen, dvs., at Sokrates designer betingelserne for, at eleven selv kan finde den viden, han allerede indeholder. Det er dette grundsyn, der ifølge Biesta umuliggør undervisning i konstruktivistisk forstand, selvom den radikale konstrukivismes fortalere mig bekendt aldrig har arbejdet med Menon-referencen. I stedet siger Biesta, at en lærer både overbringer viden, men også betingelserne for, at eleven indoptager viden som viden. Læreren er altså ikke blot en transmittør af viden eller en udspørger, men han transmitterer også betingelserne for viden, f.eks. i form af Bubers dialogiske mytologi, eller i form af den livsform, som skolen skal virke i. Det er denne dobbelte struktur, som Biesta finder hos Kierkegaard som en "åbenbaring". Også Biesta taler om, at elevens relation til læreren derved bliver "essentiel" (Biesta, 2013, s. 50). Undervisning, denne transmitterende forbindelse af indhold og indholdets betingelse, transcenderer det, som eleven allerede ved. Undervisningen kan ikke udledes af eleven overhovedet. Undervisning er en form for indbrud, et "being taught". Og vi får at vide, at "to learn from someone is a radical different experience than being taught by someone" (s. 53). Når vi bliver undervist, lærer vi noget om os selv og om vores væren og handlen i verden og knytter det til videns- og erfaringsmomenter. Det er denne sammenknytning af viden og videns betingelse, jeg selv har kaldt for en "kundskab" (Rømer, 2015). Vi lærer om "inconvenient truths og difficult knowledge" (s. 53), der bringer subjektiviteten i spil på en meget mere alvorlig måde, end hos konstruktivisten.

Den anden pointe handler om gaven: Gaven er kun en gave, hvis den modtages, og det kan ikke planlægges, men man kan holde øje med det og være opmærksom på det (deraf svagheden). En lærer er ikke en identitet, men noget man bliver, når en gave modtages, hvilket kan ske på mange forskellige måder. Vi kan derfor tale om "en sporadisk" identitet, om en undervisning som en "event". Når gaven modtages, giver man sig hen til gaven - $\mathrm{i}$ en hen-givenhed, hvorved eleven bliver til elev. Vi ender dermed i en dobbelt "gift-giving", som er en særlig lykke, ja, måske den ultimative humanitet: At give en gave, der modtages, hvorved modtageren selv erkender det som en gave og giver sig hen, altså hen-giver sig til gaven.

Derfor: "Calling someone a teacher is therefore ultimately not a matter of referring to a job title or a profession, but is a kind of compliment we pay 
when we acknowledge.... That someone has indeed taught us something ...." . Vi modtager en sandhed "for which I am willing to live and die". Det er "the truth I have managed to receive" (s. 54). Derved efterlades man i en "objektiv uvished", som Kierkegaard citeres for at kalde det.

Dermed genindsættes autoritetsbegrebet: "To receive the gift of teaching, to welcome the unwelcome, to give a place to inconvenient truths and difficult knowledge, is precisely the moment where we give authority to the teaching we receive" (s. 54). Dermed mener Biesta, at vi kan genvinde en form for kulturel og pædagogisk ligevægt efter 1968-problemerne med pædagogisk autoritet. Efter min opfattelse ligger disse refleksioner i direkte forlængelse af det, jeg beskrev ovenfor som den danske lærers essens, dvs. en form for passiv autoriet, der giver gaver tilbage, som han selv har fået, og som derved skaber folkelig tilsynekomst, og det hele bidrager direkte til en pædagogisk fortolkning af skolens formål. Forskellen er nok, at Biesta har lidt problemer med "folket". For ham bliver det til "subjektifikation", der sættes i delvis modsætning til kvalifikation og socialisation. Forskellen skyldes efter min mening en for kraftig prægningen fra Foucault (Rømer, 2017c).

\section{Undervisning som det gode pædagogiske liv}

Det tredje nedslag finder vi hos Chris Higgins i bogen The good life of teaching: an ethics of professional practice (Higgins, 2010). Bogen er en sammenskrivning af neo-aristoteliske markeringer, dvs. en diskussion af Macintyre, Taylor, Dewey, Gadamer og ikke mindst Hannah Arendt, som jo også præger Biestas filosofi.

Det vil føre for vidt at uddybe det rige væv af tanker, som denne bog indeholder, så jeg vil blot opholde mig ved nogle få forhold. Higgins forsøger at gøre undervisning til en del af en etisk livsform, en del af en praksis i græsk forstand og i egen ret. De to ledende spørgsmål er det sokratiske "hvordan bør jeg leve?" og "hvorfor undervise?" samt en undersøgelse af hvordan disse spørgsmål hænger sammen med det fælles liv. De to spørgsmål og deres ledsagende livsformer melder sig igen og igen som etiske spørgsmål, hvor menneskelig frihed er undersøgelsens formål og forudsætning, hvilket jo også ligger i mange af formuleringerne i skolelovens $\S 1$, hvor frihedsbegrebet står centralt. At undervise er altså en undersøgende, selvkultiverende og etisk livsform, der drager omsorg for genskabelsen af samfundets frihed.

De to spørgsmål kan altså ikke besvares teknisk, a la "man skal arbejde efter følgende regler vedtaget af X kommune", for dette "man" er også et 
"jeg" og aldrig blot en struktur. Dvs., at undervisning er en undersøgelse af, hvordan både jeg og "man" bør leve, og det stiller også et spørgsmål til eleven om, hvordan han eller hun bør leve, samt hvem hun er ved at blive til sammen med andre. Der er ligefrem tale om en indbygget "tension" mellem "jeg" og "man", hvilket er Higgins' version af Bubers dialogiske treenighed, som også nævnes nogle gange. En lærer er en selvkultivator, som afsætter selvkultivering hos eleven i et fælles pædagogisk liv. Der er ikke tale om et moderne selv, som skal "selvrealiseres". Det er snarere en etisk selvomsorg, som er social i dybden. Vi finder faktisk lidt af de samme referencer hos den sene Foucault, når han taler om Parrhesia, dvs. åbenhjertig tale, og om selvomsorg som centrale etiske kategorier. Foucault har dog problemer med "den anden", fordi han som regel for-strukturerer omverdenen i neo-dit og dat. I det græske begreb er praksis en fælles kultivering af begyndende selv'er, der udgår fra en fælles pædagogisk grund. Det er det, som foregår på en skole. Det er "undervisningens gode liv". Her handler det ikke om læring og adfærd, men om karakterudvikling og handling i et fællesskab, det som briterne kalder for "conduct", og om en etisk undersøgende praksis.

Det betyder ikke, at undervisningen ikke også er knyttet til indhold, tværtimod. Indholdselementer indgår i høj grad i den pædagogiske omsorg, men påvirker den også. I den forbindelse har Higgins faktisk en længere drøftelse af dannelsestraditionen og dennes postmoderne og moderne anvendelser. F.eks. har han en lang diskussion af de dannelsesprocesser, en snedker må gennemgå, når han bygger et bord. Han beskriver dannelsesprocessen som en vekselvirkning mellem hånd, materiale og håndværkstradition og fortæller om, hvordan snedkeren forlader sig selv for at finde sig selv i traditionen af andres værker. Higgins' tilgang er derfor i høj grad forenelig med både dannelsesbegrebet og situeret læring. ${ }^{4}$

Higgins mener at kunne finde denne livsform flere forskellige steder. Især finder han den hos Hannah Arendt, hvis kernebegreb er "natalitet", altså evnen til at begynde. Pædagogik ses i den forstand som at drage omsorg for disse begyndelser og deres vekselvirkning med kulturens og fagets plurale indhold og materie.

Dermed får vi et billede af en skole, hvor undervisning er en undersøgelse af, hvad man bør gøre i sammenhæng med, hvad der findes, og hvem man bliver til. Det er en form for fri, spørgende og undersøgende livsform

4 Det minder om Byung-Chul Hans "synets pædagogik", som fremstår som det modsatte af "synlig læring". Her handler det om at blive set af tingen (Han, 2010). 
og praksis, som har sin egen ret og ikke mindst sine egne "rytmer", som Higgins kalder det. F.eks. taler han om "the rhythm between withdrawal and engagement", om "characteristic patterns of planning, pursuit, and completion followed by intervals of rest and reflection" og om "a dialectic of solitude and relation", og det er faktisk i den forbindelse, at Bildung-traditionen nævnes. Higgins taler også direkte om det græske eudaimania, lykken, og om det at "leve vel" og at "fare vel" samt om Arete, det gode liv i et godt fællesskab (s.194+198). Higgins nævner også en distinktion, som Arendt trækker på, nemlig de to græske begreber for liv, zoe og bios. Det er bios, altså den etiske og fælles livsførelse, der er i centrum her, og som i modsætning til det adfærdsmæssige zoe er det specifikt menneskelige. Skolen er simpelthen lykkens sted.

Endelig markeres dette skoleideal som en "strangely radical brand of conservatism, inspiring as many on the left as on the right" (s. 200). Fuldstændig som man også kan tænke om Bubers og Biestas indsatser, der også begge forsøger at genskabe en tradition i det moderne livs omskifteligheder, og som også på en sær måde taler uden om almindelige politiske distinktioner. Selv har jeg, dog i en anden sammenhæng, brugt udtrykket "en konservativ postmodernisme" lidt i samme ånd.

En skole handler altså om det, som har værdi i sig selv, om samfundets ståsteder og om de mennesker, der skal finde dem og stå og gå der (Brinkmann, 2016).

\section{Undervisning i en suspenderet tilstand}

Den sidste pointe, jeg vil nævne, finder man hos den belgiske filosof, Jan Masschelein, som sammen med Maarten Simon har skrevet bogen In defence of the school - a public issue (Masschelein \& Simon, 2013). Masschelein trækker ligesom både Higgins og Biesta på Hannah Arendt. Franskmanden Jacques Rancière inspirerer både Biesta og Masschelein, mens Masschelein er alene om at interessere sig for den italienske filosof Georgio Agamben. Desuden arbejder den ny-fænomenologiske "weird realism" på det begrebsmæssige plan, hvilket viser sig som en kraftig interesse for ontologien og denne bevægelses centrale begreb: "Tingen" (se note 3). Masschelein deler desuden Biestas hårde kritik af læringsbegrebet, som han mener "tæmmer" skolen, hvilket står i modsætning til skolens begreb, som skal indgyde frihed i samfundet via Fri Tid. 
Ligesom Higgins genfinder Masschelein skolebegrebet i en græsk tradition og gør skolen til en fra arbejdslivet og reproduktionen suspenderet tilstand, ligesom i "den frie tid", der jo også var skolens græske betydning. Dvs., at man i skolen anskuer tingene uden for deres brugssituation og uden for "oiko-nomia", som jo er en regel ("nomos") for private og behovsorienterede kredsløb, dvs. for husholdningerne (oikos). Den suspenderede ting, dvs. indholdet, er ting uden specifik funktion og anvendelse, hvis betydning og indre man kan puffe til og dreje på, og hvis svar man kan studere. På samme måde bliver børnene i suspensionen til elever, hvor de er fri af deres sociale roller. Alle elever betragtes ud fra "lighedens forudsætning", som den franske filosof Jacques Rancière siger, og de udvikler sig i omgang med de suspenderede ting, som også udvikler sig. Skolen bliver dermed en form for åndelig og praktisk vekselvirkning i et fra samfundet suspenderet rum. Undervisning handler herefter om at bringe tingen og subjektet hen til hinanden, så denne suspenderede tilstand kan realiseres i alle mulige former for processer.

En yderligere pointe, som delvis er min egen, er det forhold, at læreren selv er forbundet med en række historier i disses frie og suspenderede former. Læreren er dialogiseret og suspenderet på samme tid. Men denne suspenderede dialogisering gør også monologen vanskelig, vi får en "tension", som Higgins siger. Det er denne spænding mellem en historisk dialog og en situationsspecifik monolog, der gør, at en god lærer altid også er lidt fjern og stammende. Måske henviser denne spænding netop til den transcendente rumlen, som Biesta har fat $\mathrm{i}$, og hvis rod er en national dialogisk humanisme a la Buber?

Masschelein forsøger på den baggrund at genfortolke en del af det, som den kritiske teori har affærdiget som "sort skole", dvs. skolens ritualer, rytmer og rutiner som forskellige former for bidrag til at betone og fremme skolens suspenderende tilstand, som altså har sit eget liv og eksistens, og hvor elev og ting bringes hen til hinanden i åbne møder. Masschelein er både skeptisk overfor alt for markante dannelsesfigurer, ikke mindst med udgangspunkt i Bildung-teorien, og overfor opløsningen af skolen i arbejdsmarkedet og det sociale liv. For ham bliver skolen og dens undervisning en suspenderet vekselvirkning mellem elev, lærer og ting. 


\section{Konklusion}

Til sidst er det på sin plads at samle op og kort vende tilbage til udgangspunktet, nemlig spørgsmålet om kausalitet. Jeg har i ovenstående betragtninger forsøgt at etablere et begreb om undervisning i sig selv som en dobbelt gavegivning, hvor en elev modtager en lærers gave, hvorved læreren bliver til lærer. Denne modtagelse er selv en gave, en given sig hen, hvilket gør eleven til elev, og dermed forbindes både lærer og elev til et pædagogisk liv, frem for blot et privat eller kausalt liv i et konstrueret bur. Undervisning bliver hermed en gaveproces og dermed et af vores fineste udtryk for humanitetens dyd. Denne proces har forskellige former for nationale prægninger, som man ikke kan eller bør undvære, hvoraf jeg omtalte både Bubers og Grundtvigs filosofi. Derudover knyttede jeg gaveprocessen til et pædagogisk liv, en suspenderet tilstand med egen normativitet og egne rytmer, som vi fandt det på forskellige måder hos både Higgins og Masschelein. Dermed får vi en tredeling: Gave, national essens og personlig og tingslig tilsynekomst. Det er det, som skolens formålsparagraf angår, og som læringsbegrebet også må underlægge sig. Efter min mening er denne tredeling ensbetydende med samfundets inderste betydning. Man kan sige, at det er samfundet, der skal tilpasse sig skolen frem for omvendt.

Men nu har jeg så etableret den uafhængige variabel i al sin fylde. Hvad så? Hvad så med kausaliteten? Ja, den må nu forstås helt anderledes. Nu må læring forstås som en del af dette gavegivende både nationale og suspenderede liv, og netop her mister processen sin karakter af "læring". Læring opsluges af undervisningens invitationer og subjektifikationsprocesser. Ja, på en måde udelukkes "læring" fra skolen, fordi det jo er en biologisk/systemisk tilstand ved mennesket, altså en del af zoe, en slags psykisk og socialt system, der kan opløses i rådata. I stedet får vi ord som tilsynekomst, hengivelse og subjektifikation, dvs. en form for "læringsglemsel", som psykologen Lene Tanggaard engang udtrykte det (Tanggaard, 2015). Denne erstatning af kausalitet med gavegivning ændrer efter min opfattelse vilkårene helt for den pædagogiske forskning. Vi får nu studiet af gavegivningen og dennes sociale og psykologiske vilkår. Pædagogisk forskning bliver til forskning i undervisning.

I den forstand kan man godt sige, at det gælder om at undgå læring. Undervisningen spytter læringen bort og indoptager eleven som menneske med kulturel eksistens i stedet for. 
Thomas Aastrup Rømer: Undervisningens gavegivning

\section{Litteratur}

Biesta, G. (2004). Against Learning - Reclaiming a Language for Education in an Age of Learning. Nordisk Pedagogik, vol. 24(1), 70-82.

Biesta, G. (2012). Receiving the Gift of Teaching: From 'learning from' to 'being taught by'. Studies in Philosophy of Education, 32(5), 449-461.

Biesta, G. (2013). The beautiful Risk of Education. Boulder: Paradigm Publishers.

Breslauer, S.D. (2016). Martin Buber's Myth of Zion: National Education or Counter-Education. Studies in Philosophy and Education, 35(5), 493-511.

Brinkmann, S. (2016). Ståsteder - 10 gamle ideer til en ny verden. København: Gyldendal Business.

Glasersfeld, E.v. (1995). Radical Constructivism - a Way of Knowing and Learning. New York: The Falmer Press.

Han, B.-C. (2010). Træthedssamfundet, Ø-bog.

Hariri, J.G. (2012). Kausal inferens i statskundskaben. Politica, vol. 44, nr. 2, 184-201.

Harman, G. (2005). Guerilla metaphysic - Phenomenology and the Carpentry of Things. Illinois: Open Court.

Higgins, C. (2010). The Good Life of Teaching. Journal of Philosophy of Education, 44(1-2), hele tidsskriftet.

Jonas, U. (2003). Poetisk videnskab - Grundtvig og Foucault. I: Slagstad, R. m.fl. (red.), Dannelsens forvandlinger. Oslo: Pax Forlag, s. 125-151.

Kemp, P. (2015). Løgnen om dannelse - opgør med halvdannelsen. København: Tiderne Skifter.

Masschelein, J. \& Simon, M. (2013). In Defence of The School - a Public Isssue. Leuven: E-ducation, Culture \& Society Publishers.

Qvortrup, L. (2015). Baggrund for diskussioner af Visible Learning med særligt henblik på lærings- og vidensbegrebet. Paideia, nr. 9, 22-33.

Staunæs, D. \& Juelskjær, M. (2014). Klasseledelse - "all inclusive": læringscentreret ledelse af sanser, affekter og rytmer. I: Kreisler, J.B., \& Moos, L., Klasseledelelsens dilemmaer fortsatte magtkampe i praksis, pædagogik og politik. Dafolo, s. 151-171.

Roth, W.-M. (2009). Dialogism - A Bakhtinian Perspective on Science and Learning. Rotterdam: Sense Publishers.

Rømer, T. (2015). Pædagogikkens to verdener. Aalborg: Aalborg Universitetsforlag.

Rømer, T. (2017a). Et kritisk lys på John Hatties teori om Visible Learning. I: Bjerre, J. m.fl., Hattie på dansk - evidenstænkningen i et kritisk og konstruktivt perspektiv. København: Hans Reitzels Forlag, s.129-160.

Rømer, T. (2017b). Niklas Luhmanns hyper-radikale konstruktivisme. på www.thomasaastruproemer.dk.

Rømer, T. (2017c). Er Gert Biesta dannelsesfilosof? I: Lærke, G., \& Morsing, O. (red.), Uddannelse for en menneskelig fremtid - Gert Biestas pædagogiske tænkning. Aarhus: Klim.

Tanggaard, L. (2015). Saglige udvidelser. I: Rahbek, R.K., \& Møller, J., Højskolepædagogik-en fortælling om livsoplysning i praksis. Aarhus: Klim. 